\title{
The role of the earth sciences in a sustainable world*
}

\author{
Institute of Geosciences, University of São Paulo, P. O. Box 11348, 05422-970, São Paulo, Brazil
}

\begin{abstract}
At the dawn of a new millennium, Geology will surely play an increasingly important role in our better understanding of the Earth, in our path towards a sustainable society. With broader application of information technology and modeling of the geological processes, Geology is becoming more and more quantitative, and better prepared to give its contribution to Earth management. This is a very complex task, since all processes on the Earth are interlinked, and hence the approach must be interdisciplinary, when the participation of geoscience professionals from different fields is essential.
\end{abstract}

\section{Introduction}

It is a great honor and a great pleasure to be able to address you on the role of the Earth Sciences at the dawn of the XXI century. This view of the future is especially pertinent because it matches the main theme of the 31st International Geological Congress: Geology and Sustainable Development: challenges for the third millennium.

My interest in this matter began with my involvement with IUGS-The International Union of Geological Sciences, UNESCO and ICSU, in the second half of the nineteen eighties. At that time I became aware of the difficulties that confronted not only Geology, but also other exact and natural sciences as well, in the face of the great changes that society was undergoing in the face of such global issues as the environment and development.

I have since been invited to speak in public on this matter on many occasions, in addition to which I have written some general articles (Cordani, 1995, 1998; de Mulder and Cordani, 1999). I remember with great pride the opportunities I had to address similar audiences at the opening sessions of two previous International Geological Congresses: those at Washington and Kyoto. On this occasion, at the opening of the 31 st International Geological Congress, here in Rio de Janeiro, I ask for your patience and your pardon for some inevitable repetition, in addition to which many of the ideas and concepts are well known to those acquainted with the subject and the utopia of sustainable development.

\section{Historical background}

Global environmental concerns developed in the second half of the XX century, when many sectors of society drew attention to the necessity for a coherent policy on the environment. When this movement began many developing countries, including Brazil, were reluctant to include environmental conservation in their plans for development. The reason for this was that some environmental degradation was considered to be the unavoidable consequence of industrial growth. This matter was discussed at some length at the

* A key address given at the Colloquium of the 31st International Geological Congress.
UN Conference on Human Environment (Stockholm, 1972), where the concepts of ecodevelopment and poverty pollution were introduced.

During the nineteen eighties, the Brundtland Commission was set up by the UN, with a mission to undertake a broad study to define the interrelationships of both the global problems of environment and development. This commission produced a well-known report entitled Our Common Future, issued in 1987, in which the concept of sustainable development was introduced. The report had worldwide repercussions, and stimulated the UN to organize the largest meeting of Heads of State in history, held in this city of Rio de Janeiro and at this very place, the Riocentro, in 1992. This historical meeting was the UN Conference on Environment and Development, also known as UNCED-92 or RIO-92, or ECO-92. The most important outcome of this conference was that it greatly increased the awareness of the global problems the world over. Public policies and national projects were reviewed and modified, and the issues of environment and development were included in the forefront of many speeches and public addresses made by businessmen, politicians, governmental officers, amongst other authorities, as well as those made by private citizens in an unofficial capacity. The RIO-92 conference gave rise to the Agenda-21, a comprehensive document accepted by all heads of state present at the conference. The document contained many proposals related to the global environment and social-economic development, written with the purpose of stimulating actions favouring the concept of Sustainable Development in the light of available technology.

As was the case in many professions, we geologists needed to consider such global issues, and adapt ourselves and our activities to the demands of society.

\section{Sustainable development}

Sustainable Development means the search for a situation of social stability for humankind in which development would be in harmony with the Earth life support systems. In such situations there would be a certain improvement of quality of life, when all the needs and some desires of the present generation would be fulfilled, without loss to the generations to follow. This paradigm comprises a balanced economic and social development, environmental protection and conservation, as well as adequate control of the strategic natural resources such as fresh water, energy and food.

A great deal of the scientific and technological knowledge needed for the acquisition of such an ideal state seems to be already available. However, in contrast, we seem to be very far from a final solution for a major problem: restraint of population growth.

Generations of Homo sapiens, perhaps one hundred thousand generations, were needed for the world population to reach the present figure of six billion people. In spite of all warnings: Malthus, the Club of Rome and the Brundtland Report, it seems unavoidable that the world population will nearly double in the next few decades. Figure 1 shows some projections of population variations for the XXI century, for a few countries. It was taken from a study made by the United Nations (Demeny, 1984), in which a few scenarios were considered; some optimistic, others less so. Figure 1 is an average esti- 
mate, according to which the world population will stabilize by the year 2050 at about 10 to 11 billions.

As you know, the Earth is finite and its life support systems are limited. The question now arises: for how many people would the Earth resources be sufficient for a decent life? This is the main issue involved in the concept of sustainability. It cannot be expressed in purely economic terms, because the global ecosystem cannot satisfy at the same time all the essential needs and all the desires of

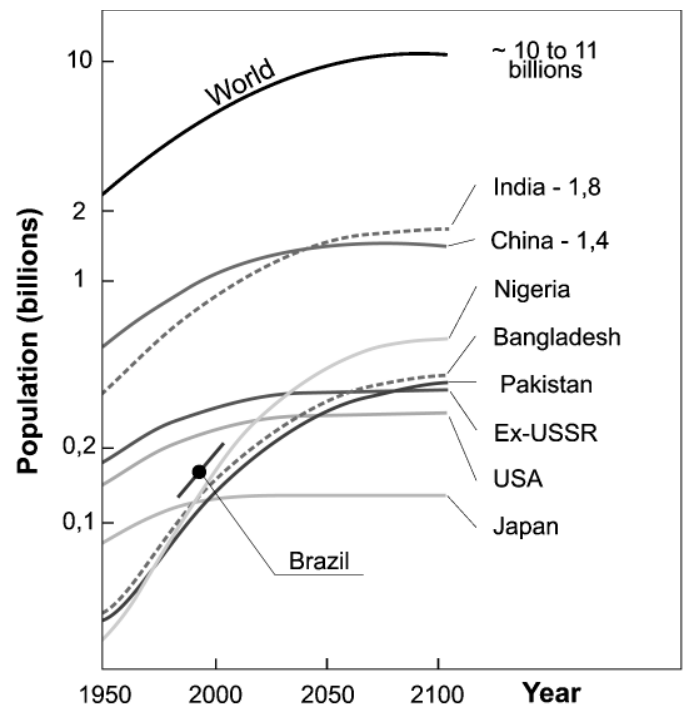

Figure 1 World population projections for next century. Source: Demeny, P., 1984.

mankind. The latter must be granted only taking into account the system's limitations, avoiding the possible wastes.

Figure 2, taken from a recent book by J. Goldemberg (1996), shows the relationship between the Human Development Index$H D I$ and annual energy consumption, for about 100 countries, in tons of oil equivalent (toe) per capita (data for 1991-1992). The HDI is a comprehensive indicator of development (or in other words quality of life), which is not purely economic, because it not only takes into account the gross domestic product of a particular country $(G D P)$, but also other items such as the illiteracy, infant mortality and life expectancy indices, amongst other factors. In figure 2 , we see that even with relatively low energy consumption ( 1 or 2 toe per capita per year) it is possible to reach values of 0.8 or 0.9 for $H D I$, which reflects favourably on the quality of life. The illustration shows very clearly the energy wastage or over consumption in many industrialized countries with similar $H D I$ values. Why is it that the energy usage per capita of the North American countries is at least twice that of the equally well-developed countries of Western Europe? What would happen to this planet if the world's population at large reached the same level of energy consumption of the United State and Canada?

Globally, such patterns are surely not sustainable. Moreover, if we recognize that Planet Earth will shortly be overpopulated, and that the environmental problems are strongly connected with the type of development that we know, it is imperative to change such paradigms for development. In the path of social-economic development, the less developed countries will probably reject the non-sustainable patterns used in the past by the industrialized countries; a pattern that has (and continues) to result in enormous wastage and over consumption. At the same time, the more developed countries will probably reduce their pressure on the Earth resources, in order to reach a reasonable global sustainability. It is my belief that some sort of social agreement must be reached between North and South. This agreement must be based upon ethical principles of human solidarity and intra (and inter) generation understanding, with a view to attaining a condition of development equilibrium and a decent lifestyle for all.

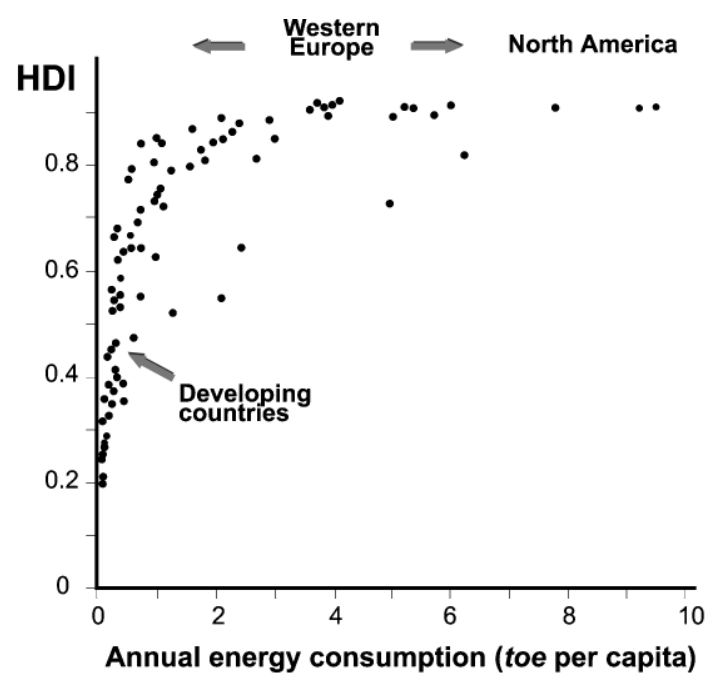

Figure 2 Human development index (HDI) versus annual energy consumption per capita 1991-1992. Source: Goldemberg, J., 1996.

\section{Global society on the eve of the third millennium}

At this stage in History, a process of globalization is in action, changing the dynamics of national societies (Cordani, 1995). It implies the intensification of social relationships on a worldwide scale, associating afar countries in such a way that local events may have their origin in those anywhere else in the world. In the new economic order, the multinational corporations are the most important players, acting worldwide in real time and influencing the behavior of many state-nations, even those of major political expression, which are frequently obliged to reformulate their national projects. Moreover, the present trends, which include free trade, market oriented economies, and widespread capitalism are not sustainable, and are far from being equitable, since they afford the main benefits of the system to the rich, and most of negative impacts to the poor.

In general, Globalization has led the world in the opposite direction from that founded on the international and social agreement mentioned above. Globalization has neither resulted in the decrease of world poverty, nor in the reduction of unemployment, and it has not brought about significant economic growth in any of the less developed countries. Moreover, in some of such countries, governments have actually been weakened in their capacity to plan and coordinate their own development. Is it possible that free market economies are able to replace government in its mission to promote worldwide economic development, catering at the same time for the social aspects inherent in a just society? Would it be viable to induce feelings of solidarity and global responsibility in the richer nations and in the richer social segments in order to obtain their spontaneous contribution to development, abdicating thus some of their privileges for the well being of the greater world society? Such issues are well known to most policy makers everywhere, and diplomatic efforts need to be made to reverse many of the current trends. Surely these are the main problems to be considered and solved by mankind in the near future.

The New World Order and the environmental issue in particular have already provoked broad transformations in all human activities. Scientists and professionals of all kinds, including those related to the Earth Sciences, have modified their activity profiles. For example, the geological surveys in most countries have been restructured with the creation or the expansion of the departments related to environmental activities, in line with specific requirements.

Economists refer to environmental impact (I) as a function of population $(\mathrm{P})$, consumption per capita $(\mathrm{C})$, and production technology that feeds that consumption $(\mathrm{T})$. 
$\mathrm{I}=\mathrm{f}(\mathrm{P}, \mathrm{C}, \mathrm{T})$

Since population and consumption per capita are bound to increase, at least in the next decades, a value of $\mathrm{T}$ close to zero is essential to sustainability, as well as to keep the environmental impact within the carrying capacity limits of the environment (Cordani, 1998). Technological knowledge is available in most cases, as for example the use of many types of clean technologies related to the environment, or many processes of industrial waste recycling, or many techniques of regenerative agriculture. With respect to mining, an occupation that comes within the domain of the Earth Sciences, sustainability is not feasible in the great majority of cases, because mineral extraction is a transitory activity and usually occupies a limited geographical space. However, the costs of adequate waste disposal and environmental restoration must be taken into account, and included in the project feasibility study from the planning phase.

\section{Geology in the service of society}

Given the scenario described above, what is the role of geology and geologists to meet the new requirements of society? Surely, scientists and professionals of the Earth Sciences will have to adjust themselves to a correct evaluation of global problems, and this involves an integrated effort by specialists in different fields. Furthermore, this calls for a certain degree of humility on the part of individual specialists, bearing in mind that the experience of individual, no matter how great, may not be enough to provide the answer to global problems.

In my view, the Earth Sciences will grow in importance for society due to the many questions and problems linked to the environment and the management of the Earth's surface. We emerged from a scientific revolution in the 1960's, the Plate Tectonics Revolution, more unified than in the past. In addition, we are taking more and more a holistic approach to the knowledge of planet Earth and we have more confidence in the way that we understand how it works. As one of the very basic natural sciences, Geology will always be a very relevant field of knowledge, to be pursued by the ever-lasting human curiosity. Basic geology is required to develop an understanding of the processes and events that operate on and within the Earth. Moreover, considering the new developments of contemporary history, the geoscientist is also expected to adjust to the demands and service of society. Some of these fields of activity of practical or applied character and with specific objectives to meet the needs of society are described below.

\section{Monitoring of the Earth System's processes}

Planet Earth exhibits intense natural dynamics with fluctuations observed in any time scale producing many different effects for human life. A task for the geoscientists is to monitor such variations and predict their effects through coordinated regional and global observations in networks of different sizes, many of them operated by international organizations such as the World Meteorological Organization (WMO), the World System of Seismic Observations (WSSO), and others. In this colloquium, Pedro Dias of the University of São Paulo and Eric Odada from the University of Nairobi will deal with climate fluctuations at the present time and during the Holocene. I will only indicate to you an example of such monitoring, in which geoscientists took advantage of observations from the geological record, obtaining hints on the functioning of our atmosphere in the near past.

It is the result of the study of the Vostok ice cores, obtained from the drilling of the Antarctic ice blanket during the last decade. From these cores, it was possible to make a direct measurement of the temperature of the air during the last 420 thousand years, spanning the last four glacial-interglacial cycles (Petit et al., 1999). This study demonstrated the strong correlation of $\mathrm{CO}_{2}$ concentration with atmospheric temperature, a factor that has a considerable bearing on understanding modern climatic change. Moreover, it showed that never, throughout this time interval, the $\mathrm{CO}_{2}$ concentration in the atmosphere reached values close to those of the 20th century. In addition, it also showed that since the beginning of the Industrial Revolution such levels increased by about $25 \%$, clearly indicating the human influence on global climate change.

\section{Exploration, management and supply of mineral resources}

These have always been the obvious and more visible task of the Geosciences in the service of society. Taking into account all kinds of human actions at the Earth's surface from house and road construction to mining, there are estimates that each individual on this planet uses annually between 10 and 12 tons of raw material (Skinner, 1989). Figure 3 was taken from a recent publication of the Mineral Information Institute, Golden, Colo, USA, and those figures correspond roughly to about 20 tons per year for each American citizen.

As you know, the role of Man in shaping the landscape is a major one. The movement of material at the surface of the Earth produced by human activity is already of the same order of magnitude as that produced by the entire Earth dynamics. Man is now the most effective geomorphologic agent, and soon he will have to produce materials for 10 or 11 billion people. We just heard Brian Skinner saying that the demand for minerals will continue to grow in the century ahead, and new niches for the mining operations will have to be found. Humans may go for ocean mining, and mineral exploration will have to go deeper in Earth. As a result, despite of industrial recycling or substitution of metals by plastics or other synthetic materials, there still will be a great deal of flow of materials at the surface of the Earth.

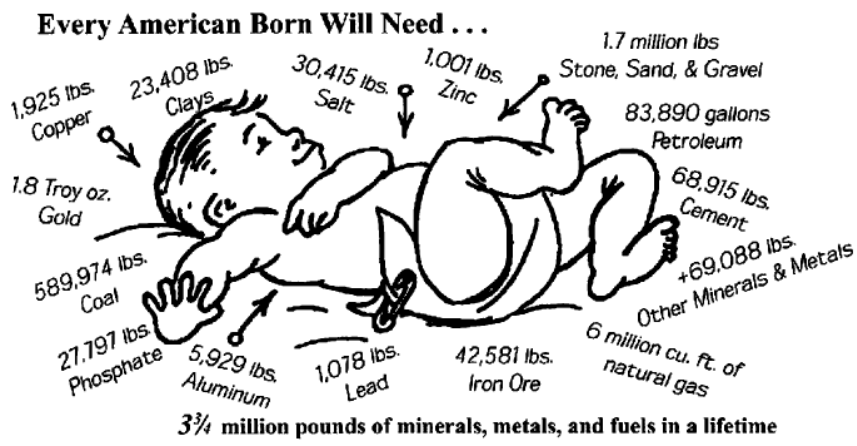

Figure 3 Estimate of the amount of material needed by each American, in his lifetime. Source: Mineral Information Institute, Golden, Colo, USA.

On account of the environmental regulations introduced in the 1980 s in many industrialized countries mining costs have been increased considerably. These countries are presently endeavoring to recover their environment, and to set conditions to keep it clean. This has led companies and investors in the mining sector to favour countries ready to offer a better balance between mineral potential and institutional framework in addition to lower costs. For example, several copper mines in Canada were closed during the last decade despite the superior quality of the ore. Their Canadian and multinational companies migrated to Chile, where they could operate well and at a lower cost. This example is a good illustration of the current trend that indicates the movement of mining sector capital toward the less developed countries with mineral potential, Brazil included (Cordani, 1995). However, since the environmental issues are expected to have equal importance the world over, the challenge in the medium term will be to find the best possible geological location and the best mining technologies. Notwithstanding, planning will be global, as will be the criteria used for the site selection for the mining operations. 


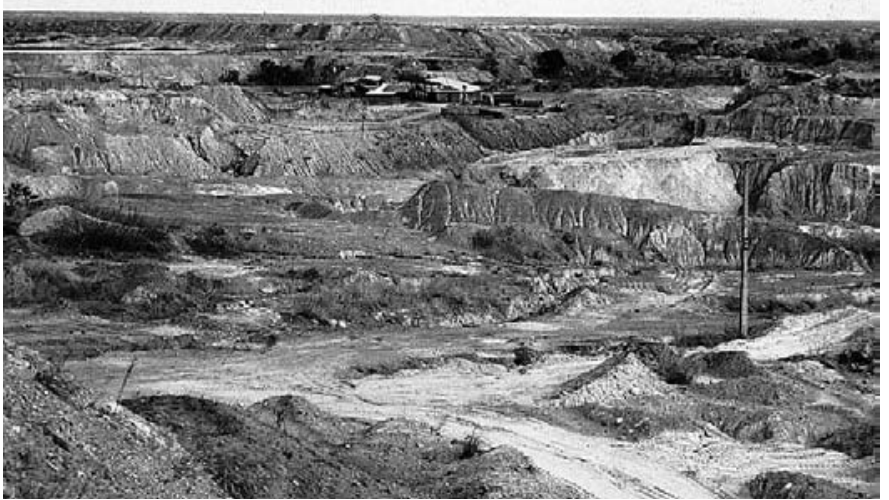

Figure 4 Degraded landscape as a result of small-scale mining activities, near the town of Poconé Mato Grosso State, Brazil. Source: Institute of Technological Research (IPT), São Paulo, Brazil.

Given this scenario, it is clear that the cost of mineral commodities to the consumer will increase as a function of environmental costs. Henceforth, the planning of mineral extraction will have to include from the start such factors as the scarcity of the commodity, the environmental pollution associated with mining, waste management, and the restoration of the landscape after the mining operation has terminated. Geologists will have to develop methods of minimizing the environmental impact involved in the mining of resources, as well as reducing the impact of the past activities of this kind. Figure 4 illustrates a situation of mining activities at the locality of Poconé, Mato Grosso State of Brazil, where predatory smallscale mining (called garimpo) was carried out in the search for gold. It shows how the environment can be affected and degraded by such activities. Figure 5, from a site at São Paulo City, shows how it was possible to clean up and restore the landscape after serious degradation, after the extraction of raw materials.

\section{Exploration, management and supply of energy resources}

A major component influencing the quality of life is the availability of adequate energy for all purposes. Our world consists of many different regions, and some nations need more energy than others. However it is also clear, from the illustration that I have already shown (Figure 2), that in some of the developed nations there may be some unnecessary waste of energy. Bill Fyfe, who I am sure is known to you all, was supposed to deal with these aspects in our Colloquium, and it is a great shame that he could not come due to sudden ill-health, from which I trust that he has now fully recovered.

At present, the bulk of world energy comes from the combustion of coal, oil and gas, and all these resources are non-renewable and non-sustainable. In addition, the burning of fossil fuels has rapidly changed the chemistry of our atmosphere and is the main factor of impact on the greenhouse effect and global warming. In this colloquium, David Roberts of BP Amoco will deal with the future of the oil industry from a geologist's point of view. He will probably say that the world oil and gas reserves, discovered and yet to find, will be enough for several decades, provided the still unexplored potential of some remote areas and deep-sea basins can be exploited, and provided recovery can be improved. In any event, if the utilization of oil and gas remains at the present rate-and that is bound to increase with population growth-these resources will have been used up in two or three centuries.

Certain countries like China and India will depend on energy from coal for long time (Fyfe, 1997), and the main contribution to sustainable development will be to improve the technology of extraction and to reduce the environmental impact of the combustion at a reasonable cost.

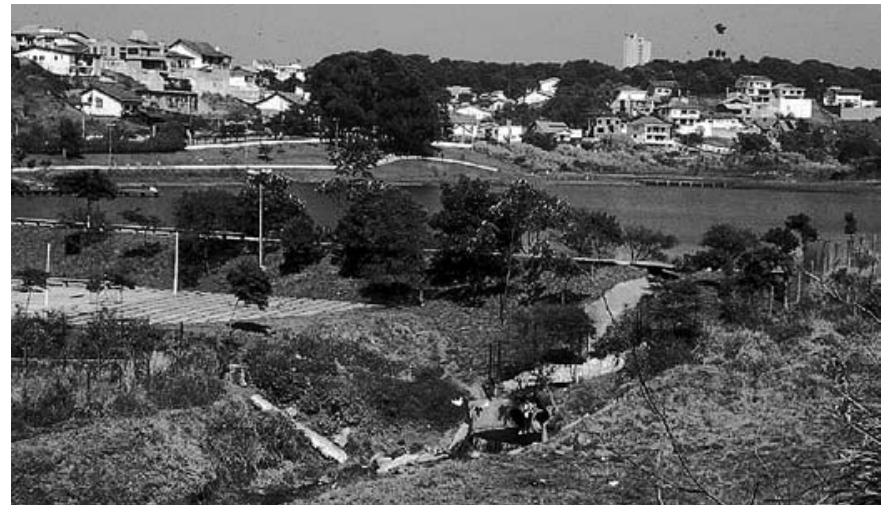

Figure 5 Example of land restoration after mining operations, São Paulo city, Brazil. Source: IPT, São Paulo, Brazil.

However, humanity will ultimately turn from the usage of fossil fuel as an energy source in favour of clean and reasonably cheap energy from renewable non-conventional sources (Fyfe, 1997). Hydroelectric power could be a good complement in the energy matrix of some regions, but is not the ultimate solution because most countries do not have enough potential in their river systems. In addition, hydroelectricity is very dependent on rainfall and climate.

Solar energy (photovoltaic, biomass, wind, tidal, ocean currents, etc.) seems to be the most adequate source for the future when the appropriate devices will become more efficient and cheaper. Geothermal energy may be developed in some volcanic regions of the globe with high heat flow such as New Zealand or Chile. Nuclear energy, largely used at present in some countries including France and Japan, has the still unresolved problem of management of the radioactive waste. The main challenges for such alternative sources of energy have been taken up by our colleagues: physicists, chemists, and engineers, who have the mission to develop the appropriate technologies. However, geologists could greatly collaborate in such regional aspects where local geology becomes important, as for example, site selection for nuclear waste disposal.

\section{Conservation and management of water resources}

Freshwater is the most important of all the natural resources. Taking the expected population growth into account, freshwater supply will be crucial for the XXI century. Table 1, taken from Rebouças, 1999, shows the main reservoirs of the Earth's surface. It indicates that the bulk of the Earth's water lies in the oceans, and Man could perhaps use this someday, if desalinization processes were to become economically feasible and technologically adequate to produce large amounts of freshwater. Freshwater represents not more than $2.53 \%$ of the total surface water, and a great deal of it makes up the groundwater aquifers. Surface waters, including those in river channels or lakes account for a little more than $0.01 \%$ of the global amount. Moreover, freshwater is not equally distributed at the surface of the Earth, and depends on regional rainfall and climatic zones. Many countries are short in freshwater, especially those of

Table 1 The Hydrosphere, water near the surface of the Earth.

\begin{tabular}{|c|c|c|c|}
\hline & $\begin{array}{c}\text { Area } \\
\left(\times 103 \mathrm{~km}^{2}\right)\end{array}$ & $\begin{array}{c}\text { Volume } \\
\left(\mathbf{x} 106 \mathbf{k m}^{3}\right)\end{array}$ & $\begin{array}{c}\text { Percentage } \\
(\%)\end{array}$ \\
\hline Oceans & 361,300 & 1338 & 96.5 \\
\hline Ground waters & 134,800 & 23.4 & 1.70 \\
\hline High latitude ice & 16,227 & 24.1 & 1.74 \\
\hline Permafrost & 21,000 & 0.300 & 0.022 \\
\hline Lakes & 2,059 & 0.176 & 0.013 \\
\hline River channels & 14,880 & 0.002 & 0.002 \\
\hline Swamps & 2,683 & 0.011 & 0.008 \\
\hline Mountain glaciers & 224 & 0.041 & 0.003 \\
\hline TOTALS & 510,000 & 1386 & 100 \\
\hline
\end{tabular}


northern Africa and the Middle East such as Libya, Tunisia, Saudi Arabia, Israel, Jordan, and others, which depend greatly on their groundwater supply.

Whereas surface waters are renewable, and their adequate management is feasible, groundwater resources are very vulnerable to any sort of pollution, and it is a major task for Earth Sciences professionals to provide for their protection, conservation and management. In many places, groundwater extraction is uncontrolled, which can lead to the aquifer depletion if recharge is insufficient. Furthermore, in vast areas bad management has led to salinization of soil and pollution by agro-chemical residues. In general, water is a multiuse resource, and its management is carried out through the control of reservoirs of all sizes. This can lead to major difficulties, because reservoirs may represent barriers to the natural transport cycle. River runoff is necessary to keep the land surface clean and especially the prevention of soil salinization.

During this colloquium, Dr. Szöllogy-Nagy, Director of the International Hydrological Program of UNESCO, will deal with this subject with the appropriate competence, and I will not expand further.

\section{Conservation and management of agricultural soils}

Soils are crucial for humanity, because they are the ultimate source of practically all elements needed for life. The geochemistry and mineralogy of soils are critical for the determination of the capacity of a soil for a sustainable organic productivity. Farming soils, the final product of rock weathering, take some thousand of years to form. According to the World Watch Institute, topsoil loss globally is approaching $1 \%$ per year, while natural replacement can take centuries. For instance, measurements of $\mathrm{Be}$ and $\mathrm{Al}$ isotopes in some Alpine regions indicated a rate of formation of about 1 or 2 centimeters of topsoil per millennium. At the same time, recent estimates obtained in some regions of the U.S. show that soil is lost at about 17 times the rate in which it is being formed (Hooke, 1999).
Some global figures made on lands from all continents account for the annual loss of 5 to 7 million hectares that slide into the oceans, without any possibility of replacement (James et al., 1992). Clearly, topsoil is a nonrenewable resource, and its adequate utilization and conservation is of fundamental importance.

Figure 6 shows a large gully, an example of erosional form in the State of São Paulo, Brazil. It is called boçoroca, and is very common in agricultural lands in such sub-tropical climate with adequate rainfall (Infanti et al., 1998). This one is seen badly affecting an urban area, well within the city of Bauru. The result of the soil loss is eventually collected as sediment deposited in some alluvial plain, or within a lake or reservoir (see for example Figure 7, related to the same erosional event of Figure 6).

Figure 8 and 9 illustrate the case of reservoir in-filling by soil erosion, also in the State of São Paulo, near Bauru. The pictures were taken before and after a serious erosional event and they illustrate the case of dams in general, and the already-mentioned problem of them acting as barriers to the natural transport cycle of sediment. The case of the High Aswan Reservoir, in Egypt, is analogous, and very illustrative. For millennia Egypt has been considered as a gift of the Nile, and agricultural crops always flourished because during the annual floods the river plains were successively filled with fertile sediments. However, since the building of the dam in the 1960s, such sediments are now accumulating within the reservoir, and the crop productivity of the country is in jeopardy.

It is perhaps worth mentioning that in a recent study carried out in two Portuguese reservoirs, the bottom sediments were considered suitable for agricultural use (Fonseca et al., 1998). This means that if sediment removal from reservoirs could be carried out economically three classical problems could be solved: dam in-filling, water quality, and soil scarcity.

These examples indicate that geologists can do much in cooperation with agro-scientists, ecologists and the like, for advice in the adequate use of soils, and in the control of soil erosion. Traditionally geologists do not involve themselves very much with soil science,

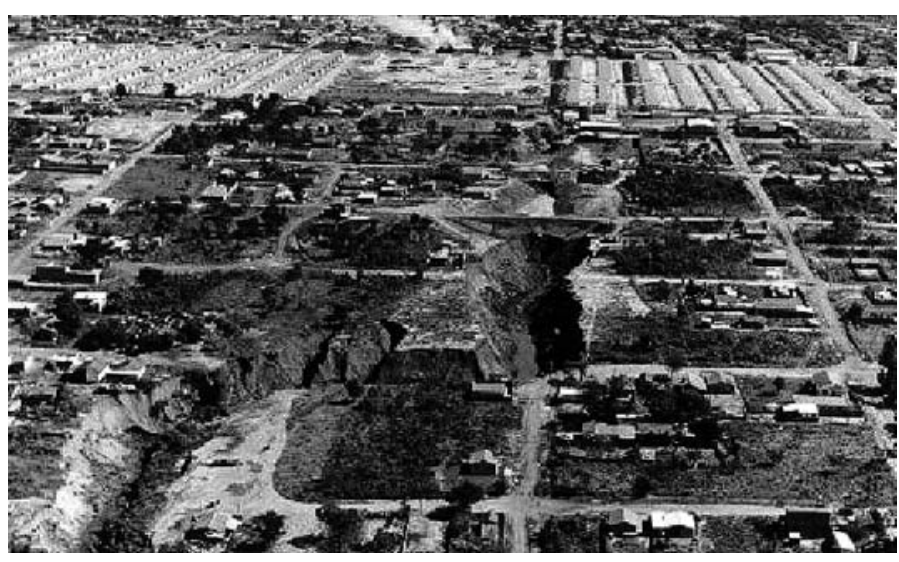

Figure 6 A large boçoroca affecting the city of Bauru, São Paulo State, Brazil. Source: IPT, São Paulo, Brazil.

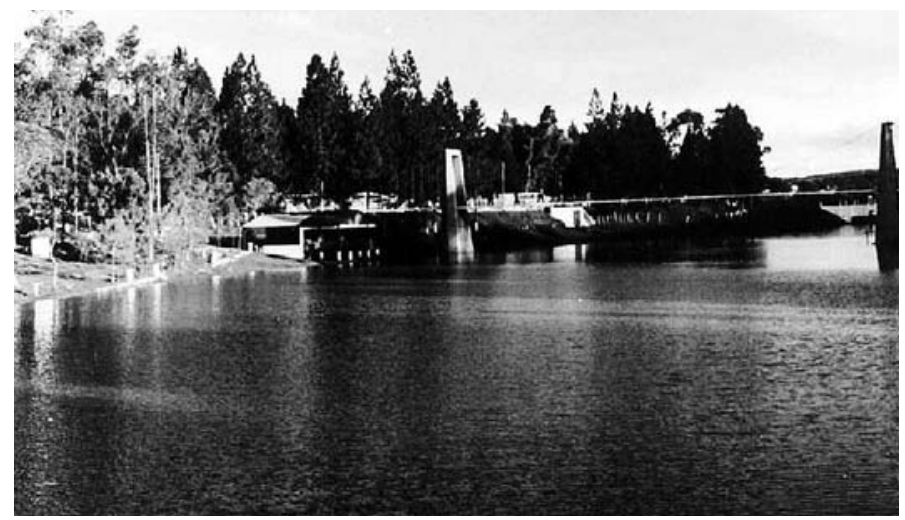

Figures 8, 9 Reservoir in-filling after soil erosion, Bauru, SP, Brazil (Before and after erosional event). Source: IPT, São Paulo, Brazil.

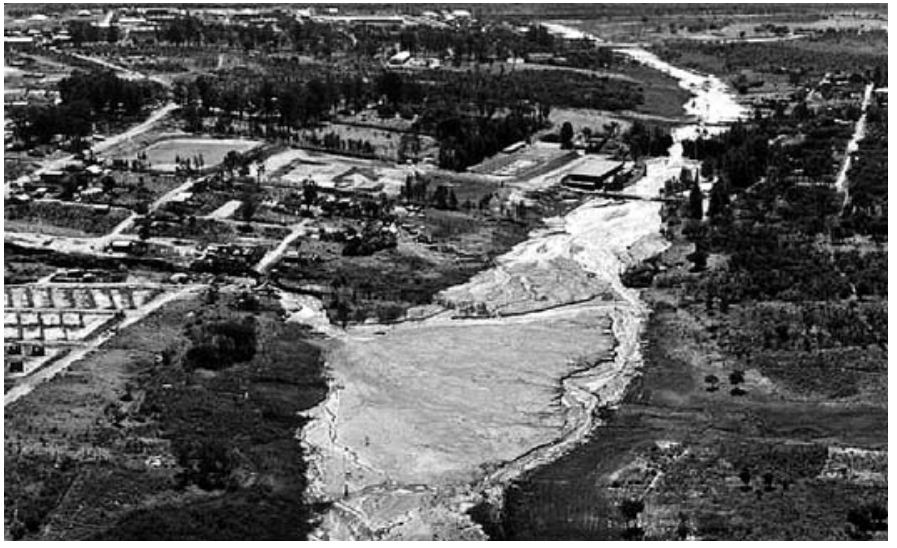

Figure 7 Sediments filling an alluvial plain at the city of Bauru, SP, Brazil. Source: Infanti Jr., N. and Fornasari Filho, N., 1998.

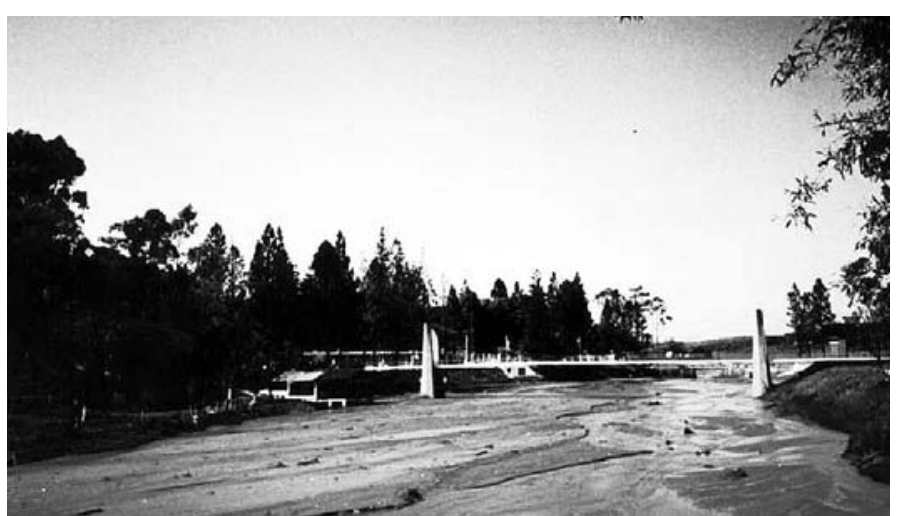


but this is surely a field of great potential for our contribution to society. Daniel Nahon from CIRAD, France will expand further on this topic in this Colloquium.

\section{Natural disasters reduction}

Natural phenomena such as earthquakes, volcanic eruptions, tropical typhoons, floods, landslides, prolonged droughts, etc. can cause catastrophes. Besides causing huge losses of human lives and property damage, such natural disasters can also bring about delays in the evolution of economic development, especially in the less developed countries. For example, let me mention the tropical cyclones and floods that affected Bangladesh in the 1970s, or the Yangtze in China in 1998; the disastrous earthquakes in Mexico and Armenia in the 1980s; the recent earthquake in Turkey; and the volcanic eruption of El Ruiz in Colombia, which triggered a disastrous landslide.

The United Nations declared the 1990s as the International Decade on Natural Disasters Reduction (IDNDR), with the main objective of improving the capacity of each country to cope with natural disasters. This would include promoting the awareness of the world about the subject, the interchange of information and expertise, and to inducing international cooperation on the subject. Figure 10 shows the observed trend in national disasters in recent years (Berz, 1993). A substantial increase in economic losses with the successive years can be seen, which is probably due, not to a real increase of endogenous phenomena of the Earth, but to a greater degree of human vulnerability. This could be attributed to several different causes, such as the enlargement of the urban areas, the occupation of hazardous sites prone to volcanic eruptions, land-

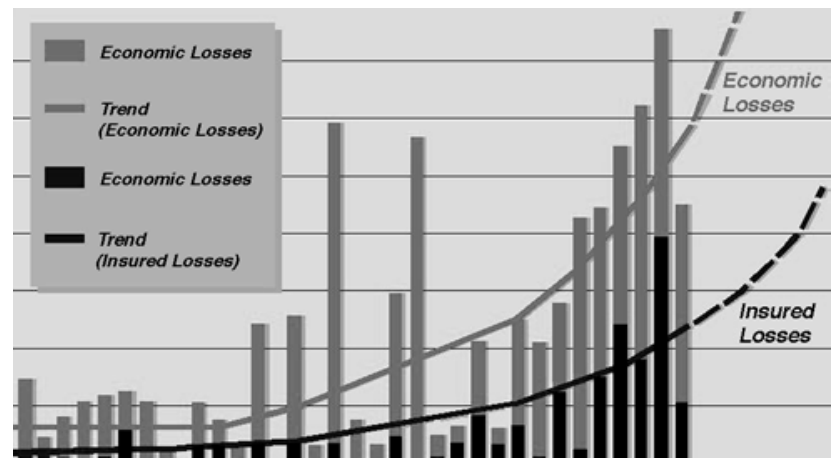

Figure 10 Losses from natural disasters, 1960-1993. Source: Stop Disasters.

slides, and floods, etc. Michel Hermelin from Colombia will deal further with this subject in this Colloquium.

In this talk I want to deal only with landslides in South America, and wish to show a few illustrations of this phenomenon in Brazil and Venezuela.

Brazil is not a particularly disaster-prone country and the more important geological hazards are related to climatic fluctuations and to the events associated to El Niño Southern Oscillations. Landslides are typical geomorphologic phenomena associated with the normal erosion cycle in tropical climates when some relief is present regionally. They are frequent, and may become disastrous when they affect populated areas or man-made structures. Figures 11 to 13 are related to some recent events in Southeastern Brazil, affecting the city of Campos do Jordão, the highway between São Paulo and Santos, and the so-called Serra do Mar Escarpment, in the State of São Paulo (Tatizana et al., 1987).

Figure 14 shows the casualties produced each year by landslides in Brazil and Figure 15 shows how the incidence of landslides can be predicted with reasonable accuracy. It comes from a time-series study of rainfall in the region of the Serra do Mar, made by the geologists of the Institute of Technological Research of São Paulo State (Tatizana et al., 1987). In this study it was concluded that there is a threshold for the triggering of landslides depending of the amount of

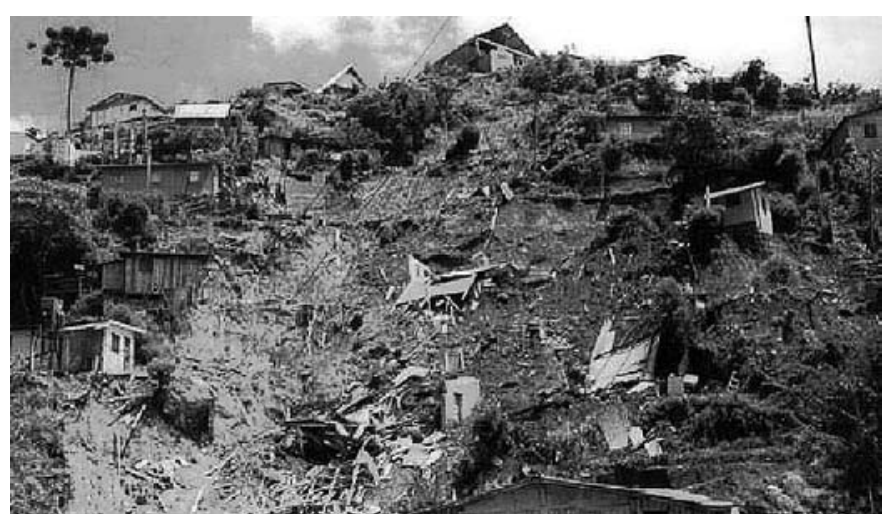

Figure 11 Landslide at Campos de Jord,,o, São Paulo State, Brazil. Source: IPT, São Paulo, Brazil.

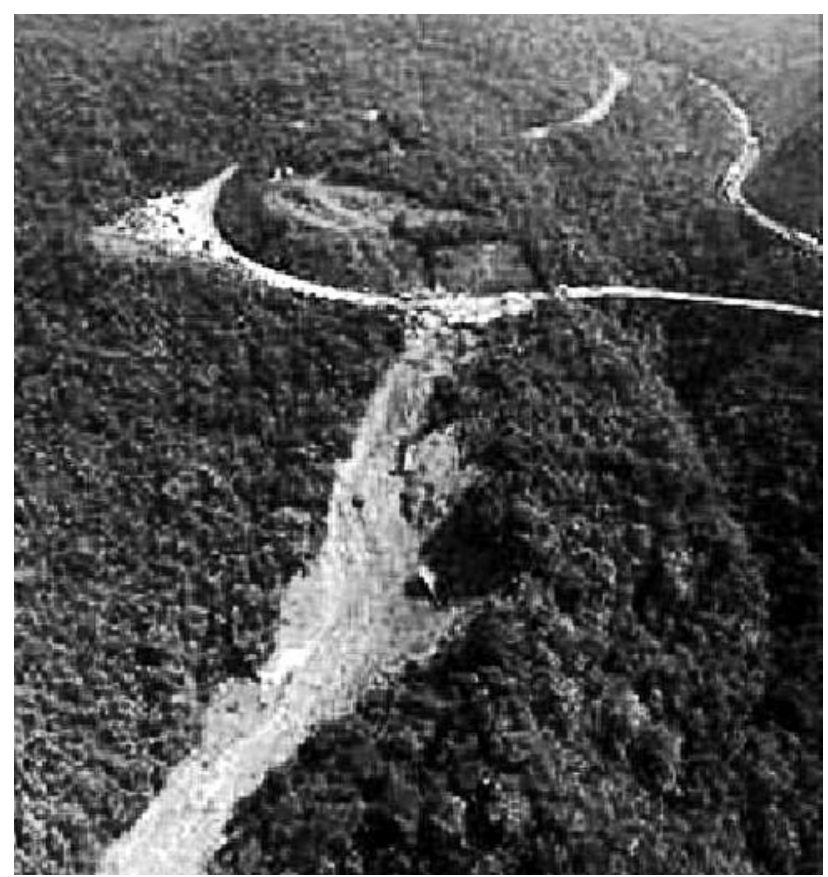

Figure 12 Landslide affecting the highway between São Paulo and Santos, at the Serra do Mar escarpment, southeast Brazil. Source: IPT, São Paulo, Brazil.

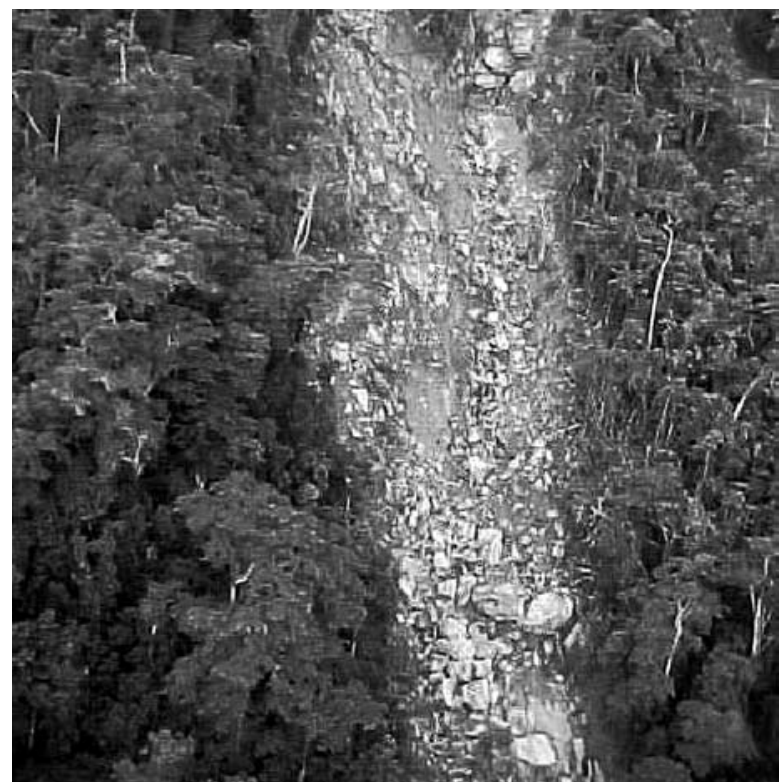

Figure 13 Landslide at the Serra do Mar escarpment, São Paulo State, Brazil. Source: IPT, São Paulo, Brazil. 
accumulated rainfall during several months, and of the amount of water produced by heavy rain during a certain short period of a few days. This figure was the basis for a successful plan of disaster prediction, warning and evacuation of the population under risk. The application of such measures by the local governments, in the last few years, certainly saved many lives in that landslide-prone region (Maceo \& Ogura, 1998).

The second example relates to Venezuela, and the terrible disasters that occurred last December. There, landslides associated with floods affected many populated areas along the Sierra de la Costa, when heavy rains occurred during a short period of several days. Figures 16 and 17 show the effects of the disasters. The first one corresponds to the locality of Los Corales, and the second is at the site of the Simon Bolivar University near Caracas.

On the matter of natural disasters, and within the aims of the IDNDR, international cooperation is very important. Geologists have a great deal to say, and in this field problems at a regional scale require actions at a much smaller scale, where the responsibility of decisions must be shared with the local authorities.

\section{Conclusions}

As already stated, at the dawn of a new millennium, I am sure that Geology, along with other sciences, will have an increasingly important role to play in all issues related to a better understanding of the Earth in our path towards a sustainable society. Geology is shifting more and more to a global and to an Earth-as-a-system perspective. It is also becoming more quantitative, with broader application of information technology and modeling of the geological processes that bear on the nature and evolution of the Earth.

We now need to make geology more visible to society. Geology is not, at present, part of the popular culture. We need to show educators all over the world how our science is important for society, and especially we require to bring pressure for the re-introduction of Earth Science curricula into the educational programs. This should occur preferably at the secondary school level, when students are being introduced to the environment and to the serious problems that face it. The objective is not necessarily to encourage young men and woman to follow a profession in the geological sciences, but rather to inform those in other areas, and especially those who may devote their lives to public service, of the fundamental importance of Geology to society.

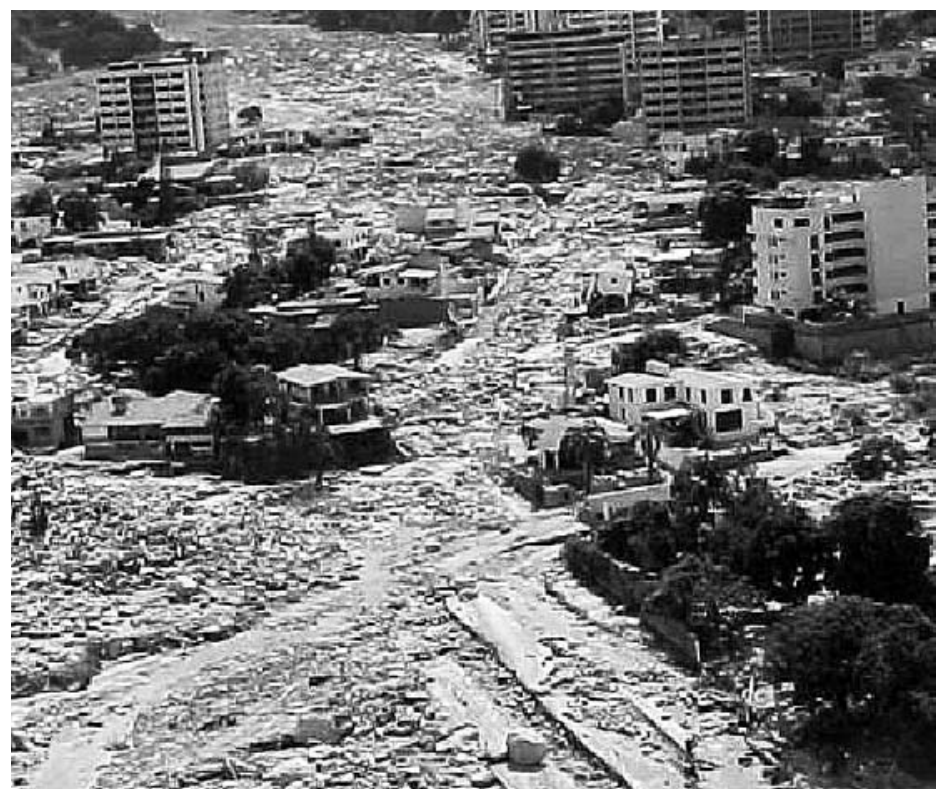

Figure 16 Disastrous landslide affecting the city of Los Corales, Venezuela, Dec. 1999. Source: Soc. Venezolana de Geologia, Caracas, Venezuela.

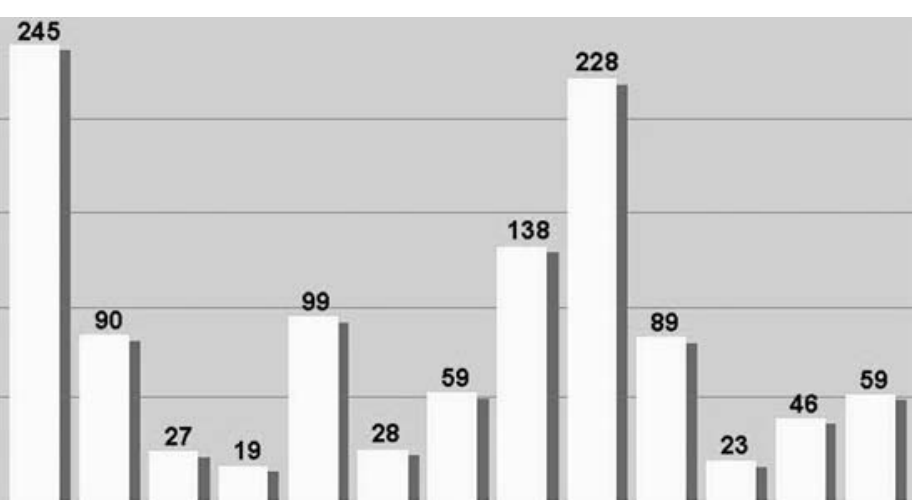

Figure 14 Deaths caused by landslides in Brazil, since 1988. Source: IPT, São Paulo, Brazil.

We also have to communicate easily with policy makers and planners. Earth management is becoming an increasingly complex task, and correct development planning is necessary to avoid irreparable mistakes. In many cases, for major decisions on large regions and complex ecosystems, the existent factual data lack precision, the estimated values are not reliable, risks are high, and yet the need of a decision is urgent. The interdisciplinary approach is then essential, and the participation of geoscience professionals from different fields is definitely needed. The approach must be holistic, because all processes on the Earth are interlinked. For any major

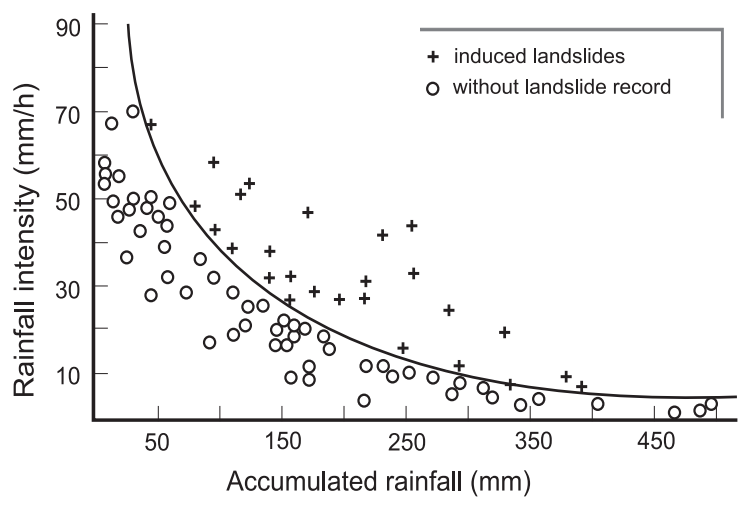

Figure 15 Diagram showing the incidence of landslides in the Serra do Mar region of southeastern Brazil, as a function of rainfall. Source: Tatizana, C., Ogura, A.T., Cerri, L.E.S. and Rocha, M.C.M., 1987.

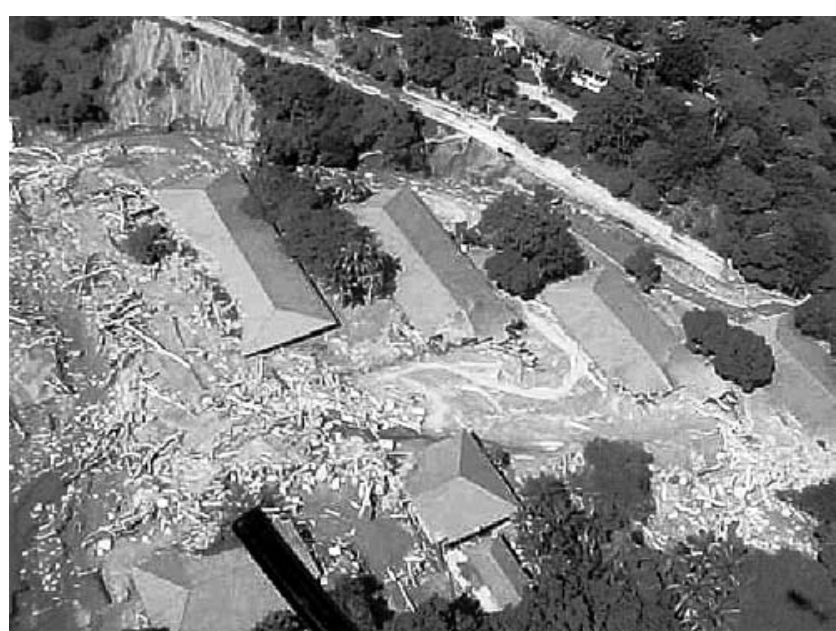

Figure 17 Disastrous landslide associated with flood at the University Simon Bolivar, Venezuela, Dec. 1999. Source: Soc. Venezolana de Geologia, Caracas, Venezuela. 
planning-water, energy, soil, mineral supply, etc.-integration of knowledge and experience from several areas of science and technology is essential, and we geoscientists must play our role.

I will conclude my talk with the same motto I used some time ago, during the opening speech at the 28th International Geological Congress, in Washington, when I was speaking in behalf of IUGS (Cordani, 1989). Sir Francis Bacon produced it in the 17th century:

"Nature to be commanded must be obeyed".

\section{Acknowledgements}

I wish to express my gratitude to several colleagues of the Institute of Geosciences of the University of São Paulo (USP), and of the Institute of Technological Research of the State of São Paulo (IPT) for the stimulating discussions on the subject. Among others, I am especially indebted to Fabio Taioli, Omar Y. Bitar and Eduardo S. de Macedo. IPT is also acknowledged for the permission of use of several illustrations included in this article. I am grateful to Marcus V. Waring for a careful revision of the English manuscript.

\section{References}

Berz, G., 1993, The industry and IDNDR: common interests and tasks, Stop Disasters: IDNDR Newsletter, 15: 8-10.

Bitar, O.Y., 1997, Mineração e sustentabilidade ambiental na região metropolitana de São Paulo, in Semin.rio sobre Ciência e Desenvolvimento Sustentável: IEA/CEPA, USP, 207-228.

Cordani, U.G., 1989, Nature to be commanded: Episodes, 12 (3): 159-161.

Cordani, U.G., 1995, As Ciências da Terra e a mundialização das sociedades: Estudos Avançados, 9: 13-27.

Cordani, U.G., 1998, Geosciences and Development: The role of the earth sciences in a sustainable world: Ciência e Cultura, 50 (5): 336-341.

De Mulder, E.F.J. and Cordani, U.G., 1999, Geoscience provides assets for sustainable development: Episodes, 22 (2): 78-83.

Demeny, P., 1984, A perspective on long-term population growth: Popul. Develop. Rev., 10: 103-126.

Fonseca, R., Barriga, F.J.A.S. and Fyfe, W.S., 1998, Reversing desertification by using dam reservoir sediments as agriculture soils: Episodes, 21 (4): $218-224$.

Fyfe, W.S., 1997, Earth system science for the 21 st century: towards truly sustainable development: Episodes, 20 (1): 3-6.

Goldemberg, J., 1996, Energy, environment and development into the 21st century: Earthscan Publ. Ltd., London, UK.
Hooke, R.L., 1999, Spatial distribution of human geomorphic activity in the United States: comparison with rivers. Earth Surf. Process. Landforms, 24: 687-692.

Infanti Jr., N. and Fornasari Filho, N., 1998, Processos de Dinâmica Superficial. in A.M.S. Oliveira and S.N.A. de Brito, eds, Geologia de Engenharia: ABGE, São Paulo, Brasil, 131-152.

James, C., Norse, D., Skinner, B.J. and Zhao, Q., 1992, Agriculture, land use and degradation. in ASCEND 21: 79-90: Univ. Press, Cambridge, UK.

Macedo, E.S. and Ogura, A.T., 1998, Landslide warning system in Serra do Mar slopes, São Paulo, Brazil. in D. Moore and O. Hungr, eds., Proc. 8th Int'1 Congress IAEG: 1967-1971.

Petit, J.R. et al., 1999, Climate and atmospheric history of the past 420,000 years from the Vostok ice core: Antarctica. Nature, 399: 429-436.

Rebouças, A.da C., 1999, Àgua doces no mundo e no Brasil. in A. da C. Rebouças, B. Braga, and J.G.Tundisi, eds., Àguas doces no Brasil. Capital ecológico, uso e conservação: Escrituras Editora, São Paulo, Brasil: 137.

Skinner, B.J., 1989, Resources in the 21 st century: Can supply meet needs?: Episodes, 12: 267-275.

Tatizana, C., Ogura, A.T., Cerri, L.E.S. and Rocha, M.C.M., 1987, An·lise da correlação entre chuvas e escorregamentos na Serra do Mar, Municipio de Cubatão. in Anais do 5o Congresso Bras. Geol. De Engenharia: ABGE, vol.2: 225-236.

UN World Commission on Environment and Development, 1987, Our Common Future: University Press, Cambridge, UK.

Umberto G. Cordani, former President of IUGS (1988-1992), graduated from University of São Poulo, Brazil, where he made a complete academic career up to the position of Full Professor in 1980. He was Director of the Institute of Geosciences and of the Institute of Advanced Studies in the same University, where he presently occupies the position of Chairman of the International Cooperation Commission. He was the President of the 31st International Geological Congress held in Rio de Janeiro, Brazil in 2000.

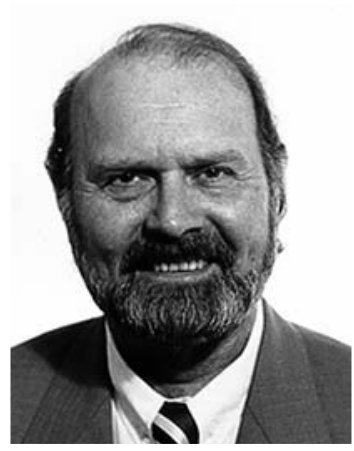

